\title{
Oral hygiene and oral health in older people with dementia: a comprehensive review with focus on oral soft tissues
}

\author{
Suzanne Delwel ${ }^{1,2}$ (ID $\cdot$ Tarik T. Binnekade ${ }^{1}$ Roberto S. G. M. Perez ${ }^{3}$. \\ Cees M. P. M. Hertogh ${ }^{4} \cdot$ Erik J. A. Scherder $^{1} \cdot$ Frank Lobbezoo $^{2}$
}

Received: 3 April 2017 / Accepted: 24 October 2017 /Published online: 15 November 2017

(C) The Author(s) 2017. This article is an open access publication

\begin{abstract}
Background The number of older people with dementia and a natural dentition is growing. Recently, a systematic review concerning the oral health of older people with dementia with the focus on diseases of oral hard tissues was published.

Objective To provide a comprehensive literature overview following a systematic approach of the level of oral hygiene and oral health status in older people with dementia with focus on oral soft tissues.

Methods A literature search was conducted in the databases PubMed, CINAHL, and the Cochrane Library. The following search terms were used: dementia and oral health or stomatognathic disease. A critical appraisal of the included studies was performed with the Newcastle-Ottawa scale (NOS) and Delphi list.
\end{abstract}

Electronic supplementary material The online version of this article (https://doi.org/10.1007/s00784-017-2264-2) contains supplementary material, which is available to authorized users.

Suzanne Delwel

s.delwel@vu.nl

1 Faculty of Behavioral and Movement Sciences, Department of Clinical Neuropsychology, VU University, Amsterdam, The Netherlands

2 Department of Oral Kinesiology, Academic Centre for Dentistry Amsterdam (ACTA), Faculty of Dentistry, University of Amsterdam and Vrije Universiteit Amsterdam, Gustav Mahler Laan 3004, 1081, LA Amsterdam, The Netherlands

3 Department of Anesthesiology and Amsterdam Public Health Research Institute, VU University Medical Centre, Amsterdam, The Netherlands

4 Faculty of Medicine, Department of Elderly Care Medicine, VU University Medical Centre, Amsterdam, The Netherlands
Results The searches yielded 549 unique articles, of which 36 were included for critical appraisal and data extraction. The included studies suggest that older people with dementia had high scores for gingival bleeding, periodontitis, plaque, and assistance for oral care. In addition, candidiasis, stomatitis, and reduced salivary flow were frequently present in older people with dementia.

Conclusions The studies included in the current systematic review suggest that older people with dementia have high levels of plaque and many oral health problems related to oral soft tissues, such as gingival bleeding, periodontal pockets, stomatitis, mucosal lesions, and reduced salivary flow.

Scientific rationale for study With the aging of the population, a higher prevalence of dementia and an increase in oral health problems can be expected. It is of interest to have an overview of the prevalence of oral problems in people with dementia. Principal findings Older people with dementia have multiple oral health problems related to oral soft tissues, such as gingival bleeding, periodontal pockets, mucosal lesions, and reduced salivary flow.

Practical implications The oral health and hygiene of older people with dementia is not sufficient and could be improved with oral care education of formal and informal caregivers and regular professional dental care to people with dementia.

Keywords Dementia $\cdot$ Older people $\cdot$ Elderly $\cdot$ Aged · Gerodontology $\cdot$ Oral health $\cdot$ Oral hygiene $\cdot$ Stomatognathic disease

\section{Introduction}

Aging of the world population has occurred at an unprecedented rate in the twentieth century and is forecasted to increase further [1]. Given the increase of general health problems with aging [2], 
and the presence of many interactions between general health and oral health [3, 4], an increase of oral health problems is to be expected.

Common oral health problems in older people are caries, periodontitis, reduced salivary flow, candida, and mucosal lesions [5, 6]. In developed countries, caries has a high prevalence in older adults with a mean number of decayed and filled coronal surfaces ranging from 22 to 35 and a mean number of decayed and filled root surfaces ranging from 2.2 to 5.3 [6-8]. In developing countries, these data are scarce [6]. Furthermore, periodontal disease is frequently present in older adults [9]. Specifically, mild periodontitis, with periodontal pockets of $4-5 \mathrm{~mm}$, is present in $62-97 \%$ of the older persons [9]. More severe periodontitis, with pockets of $6 \mathrm{~mm}$ or more, is present in $20-48 \%$ of the older persons [9]. In addition, the prevalence of oral dryness increases with age, affecting approximately $30 \%$ of the older adults [10, 11]. Salivary flowrate decrease can result in difficulties with swallowing, eating, and communication [11]. Moreover, reduced salivary flow can cause halitosis, a higher prevalence of inflammation of the mucosa and parotid, candidiasis, dental caries in dentate persons, and frictional lesions in denture wearers [11]. The majority of oral diseases, including oral cancer, occur in older adults [12]. Among oral mucosal lesions, denture-related lesions, such as stomatitis, angular cheilitis, ulcers, and hyperplasia, are most common [13]. The above-mentioned oral health problems do not only affect oral health and functioning but may also cause orofacial pain or discomfort, and can have a negative impact on the quality of life [14, $15]$.

Compared to older people who are cognitively intact, older people who develop dementia are at increased risk of establishing oral health problems, as a result of decline in self-care and motor skills [16, 17]. Conversely, tooth loss and periodontitis may be risk factors for cognitive decline, although the exact presence and causality of the association between oral health problems and the development of dementia remains unclear [18, 19].

Several studies described oral disease as a risk factor for the development of dementia, but did not provide separate oral health data for the group of participants with dementia [20-27]. It is important to have an up-to-date overview of the oral health of older people with already present dementia, because the number of older people with natural dentition and possible risk factors for dementia is still increasing. Therefore, the aim of this study was to provide an up-to-date overview of studies about oral health in people with dementia. A previous review focused on dental hard tissues [28] and this review will aim at the oral soft tissues and oral hygiene of older people with dementia.

\section{Material and methods}

For this review, the PRISMA statement [29] was followed and a protocol for the review process was developed in advance.
The main question for the review was what is the prevalence of oral health problems in older people with dementia? The subquestion was how is the oral health of older people with dementia, compared with older people without dementia? The search terms were oral health, stomatognathic disease, and dementia. No separate oral health terms were used for the main search. The multidisciplinary team consisted of a professor in dentistry (FL), a professor in neuropsychology (ES), a professor in geriatric medicine and ethics $(\mathrm{CH})$, a professor in palliative care and specialist in methodology (RP), a dentist with experience in gerodontology (SD), and a neuropsychologist with experience with older people with dementia (TB).

\section{Criteria}

Studies that were included were (randomized) controlled trials and observational studies with and without control groups (cohort, case-control, cross-sectional). Studies that were not included were reviews and case reports. The inclusion criteria for this study were diagnosis of dementia, age 60 years or older, useable quantitative data concerning oral health in a group of participants with dementia, and stomatognathic disease.

\section{Search}

The search strategy was developed in collaboration with the university library of the VU Medical Centre in Amsterdam. The search was performed in PubMed, CINAHL, and the Cochrane Library. The last updated search was performed on 12 January 2017. In PubMed, the following search query was used: ((((“Oral Health”[Mesh] OR “Oral Health” [tiab])) OR "Stomatognathic Diseases"[Mesh])) AND (("Dementia"[Mesh] OR "Dementia"[tiab])). In CINAHL: (((MH “Oral Health” OR TI”Oral Health” OR AB”Oral Health") OR (MH "Stomatognathic Diseasest" OR TI"Stomatognathic Diseases" OR AB"Stomatognathic Diseases")) AND (MH "Dementia+" OR TI "Dementia" OR AB"Dementia")). In the Cochrane Library: ("Oral Health" or "Stomatognathic Diseases") AND "dementia". No limits were applied to the search for language, year of publication, or methodology.

\section{Study selection}

The titles, abstracts, and full texts in Dutch, English, and German were screened independently by two reviewers (SD and TB) according to the pre-established protocol and the inclusion and exclusion criteria mentioned above. Disagreements between reviewers were resolved by 
consensus. Articles in languages other than Dutch, English, or German were assessed by a native speaker with a background in dentistry, after instruction by the authors. If the diagnosis dementia or data related to oral health were unclear, the corresponding authors were contacted, up to a maximum of three times over a period of 4 months. If this did not lead to usable data, the article was excluded.

\section{Critical appraisal}

The risk of bias within studies was critically appraised by two reviewers (SD and TB). For cross-sectional, case-control, and cohort studies, the Newcastle-Ottawa scale (NOS) was used [30] and for (randomized) controlled trials the Delphi list [31]. The diagnosis of dementia was considered adequate if the following criteria for dementia diagnosis were used: the Diagnostic and Statistical Manual of Mental Disorders (DSM-III and IV) [32], International Classification of Disease (ICD-9 and 10) [33], and the Alzheimer's criteria by the National Institute of Neurological and Communicative Disorders and Stroke and the Alzheimer's disease and Related Disorders Association (NINCDS-ADRDA) [34, 35].

For studies with cases (with dementia) and controls (without dementia), the groups were considered comparable if the group means for age and gender were not statistically different at the .05 level.

The oral health examination was considered adequate if a structured dental examination by a dentist took place. The person who performed the oral health examination was considered 'blinded' if (s)he did not know the cognitive status of the participants in advance. The follow-up of cohort studies was considered long enough if it was longer than 3 months and considered adequate if not more than $20 \%$ of the participants was lost to follow-up.

\section{Data extraction}

The data extraction was performed by one reviewer (SD) and was checked by two other reviewers (TB and FL). The following data was extracted: (1) participant characteristics, including age and dementia diagnosis, (2) study design, e.g., cross-sectional, case-control, cohort study, or (randomized) controlled trial, and (3) baseline outcome measures, including periodontal health and treatment need, oral hygiene, assistance need with oral care, oral mucosal status, and salivary flow. The principal outcome measures were means and percentages. The methodological and clinical heterogeneity of the data was checked.

\section{Results}

\section{Search results}

The search yielded a total of 561 articles and after adjusting for duplicates, 548 studies remained. Of these, 445 studies were excluded based on title and abstract. The full texts of 103 studies were assessed in more detail, and 67 were subsequently excluded. Supplementary list 1 provides an overview of articles that were excluded after full text screening, including the reasons of exclusion. After screening the reference lists of the remaining 35 articles, 1 study was added. The flowchart of the search is presented in Fig. 1. A total of 36 studies met the inclusion criteria and were processed for critical appraisal and data extraction. During the review process, 14 authors were contacted for further information, and 11 of them responded (see Acknowledgements).

\section{Study characteristics}

An overview of the 36 included studies is presented in Table 1; 14 were cross-sectional studies, 10 were case-control studies, 10 were cohort studies, and 2 were (randomized) controlled trials. Most of the studies were in English; the article of Sumi et al. was in Japanese [65]. All papers, except for the Japanese study, were assessed by the authors SD and TB. The Japanese study was assessed by a native Japanese speaker with dental knowledge (EY, see Acknowledgements).

Various dementia subtypes were reported in four studies $[46,61,66,67]$, and various dementia severities were reported in six of the studies [36, 46, 61, 66-68]. Five studies described the oral health of nursing home residents [53, 72-75], including people with dementia, but did not provide separate data for people with and without dementia.

\section{Critical appraisal}

The results of the critical appraisal with the Newcastle-Ottawa scale are presented in Supplementary Table 1a-c. The total scores of the 34 articles appraised with the NOS ranged from 1 to 9 , the mean score was 4.8 (SD 1.9), and the median was 5.0. Thirteen studies scored below and 12 studies scored above the median score. Hereafter, the separate NOS categories will be discussed. The DSM or ICD was used for the classification of the dementia diagnosis in half of the studies. The cases, i.e., older people with dementia, demonstrated good representativeness of the group of older persons with dementia in $24(=70.6 \%)$ of the 34 studies. The controls, i.e., older people without dementia, came from other sources than the cases in $12(=35.3 \%)$ of the 34 studies. For respectively $16(=47.1 \%)$ and $14(=41.2 \%)$ of the studies, age and gender were comparable between the groups with and without dementia. A standardized structured dental examination by a dentist was done in $29(=85.3 \%)$ of the studies. The non-response 
Fig. 1 Flow chart

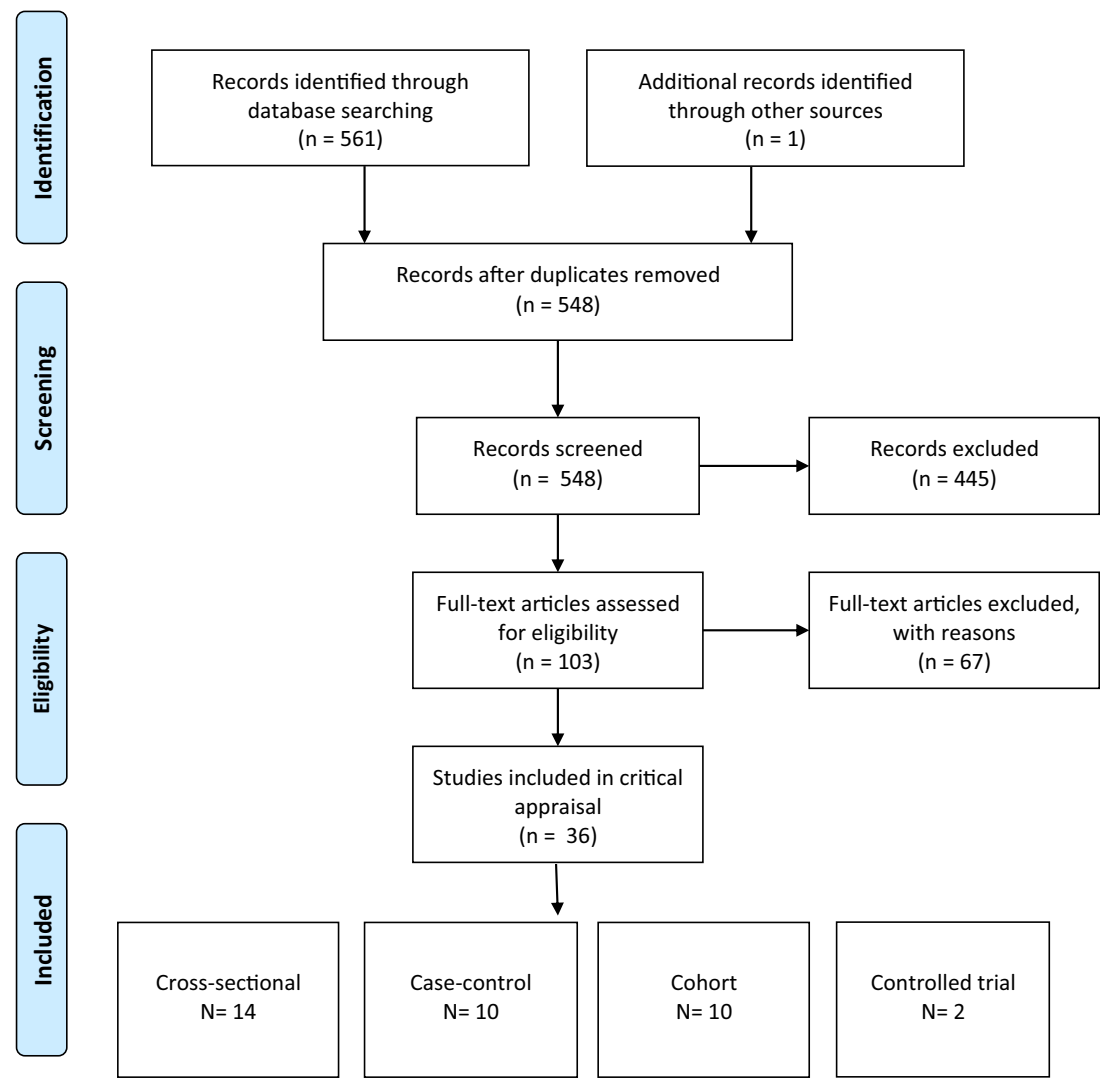

rate was described in only $2(=8.3 \%)$ of the 24 non-cohort studies. The follow-up period was longer than 3 months in 9 out of 10 (=90.0\%) cohort studies. The number of subjects lost to followup was described in 4 of $10(=40.0 \%)$ of the cohort studies.

The results of the critical appraisal of the two (randomized) controlled trials with the Delphi list are presented in Supplementary Table 2.

\section{Individual outcome variables}

\section{Gingival and periodontal disease}

Table 2 and 3 show gingival and periodontal disease in older people with dementia in percentages and means. Gingival bleeding was absent in 0.0 to $9.4 \%$ of the participants with dementia [41, 64]. Consequently, most of the participants had gingival bleeding or inflammation [40, 42, 60]. More specifically, gingivitis was present in 13.6 to $38.9 \%$ [45, 46, 55], moderate periodontitis in 6.9 to $36.0 \%$, and severe periodontitis in 11.9 to $24.5 \%$ of the participants with dementia [41, 46, $55,75]$. The mean percentage of the Gingival Bleeding Index was $46.0 \%$ in a study by De Souza Rolim [46] and 43.8$53.8 \%$ in the publications by Zenthöfer [68, 70, 76].

When examining studies that compared gingival and periodontal disease of participants with and without dementia, seven studies showed no significant differences $[44,53,59,60,66,70$, 75] and six studies showed significantly more (severe) periodontal disease in older people with dementia $[42,46,50,67,68,70]$. De Souza Rolim et al. reported significantly more periodontal infection in participants with dementia $(58.6 \%)$ than in participants without dementia (26.7\%) [46]. Zenthöfer et al. found significantly more periodontitis in participants with dementia $(100.0 \%)$ than in participants without dementia (73.9\%) [68]. Furthermore, the community periodontal index of treatment needs was significantly higher in participants with dementia (3.1-3.4) than without dementia (2.7-2.8) [68, 70]. When specifically looking at nursing home residents, a significantly higher percentage of participants with dementia had a high amount of calculus, plaque, or gingival bleeding (40.4\%), when compared to people without dementia $(26.2 \%)$. A study by Warren et al. found that the Gingival Index was significantly higher in people with Alzheimer's disease (1.1) than in people without dementia (0.7), while people with dementia other than Alzheimer's disease scored not significantly different (0.9) from people with Alzheimer's disease and people without dementia [67].

\section{Oral hygiene and assistance need}

Table 4 and 5 show the oral hygiene measures in percentages and means in older people with dementia, compared with older 


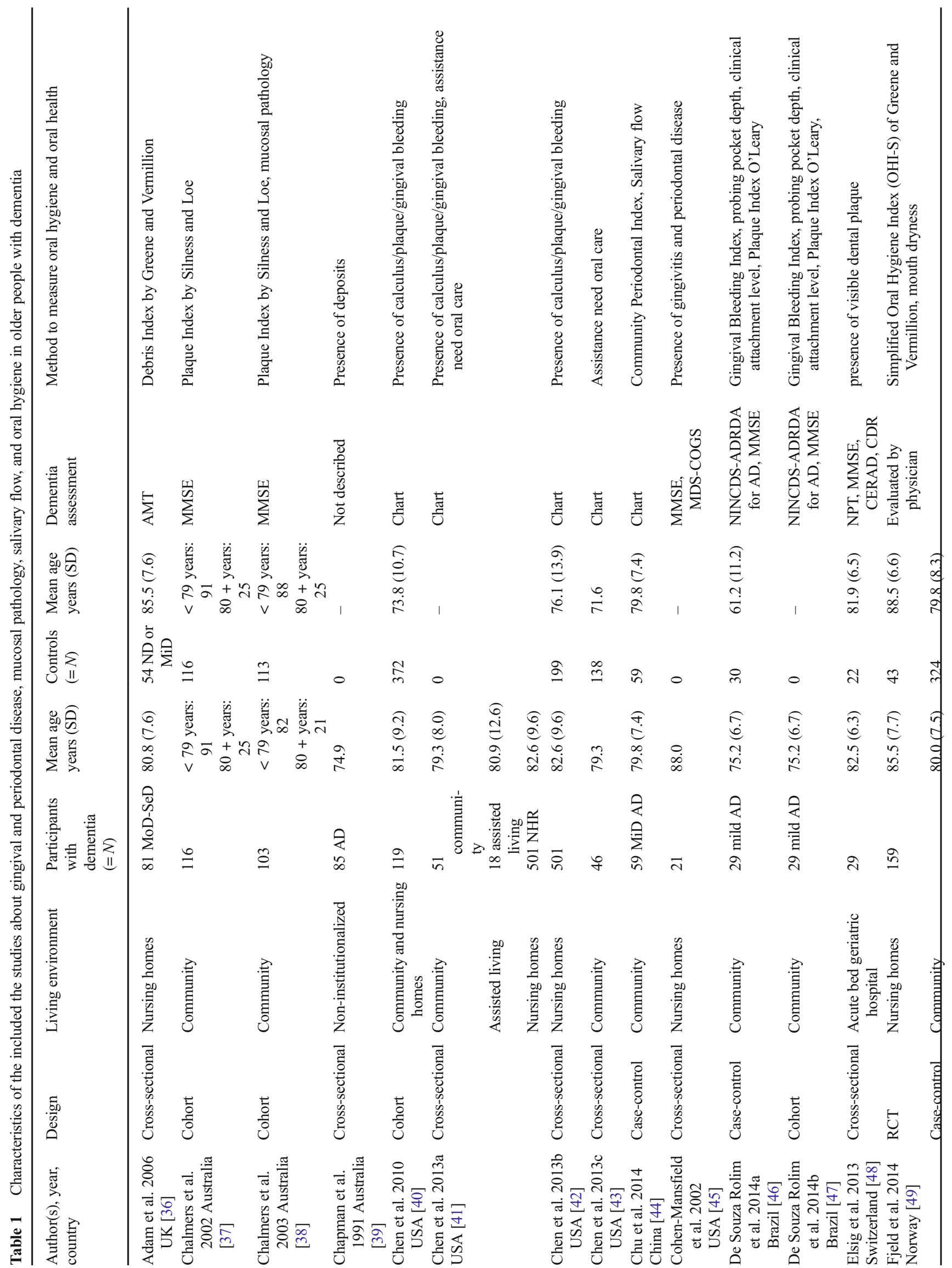




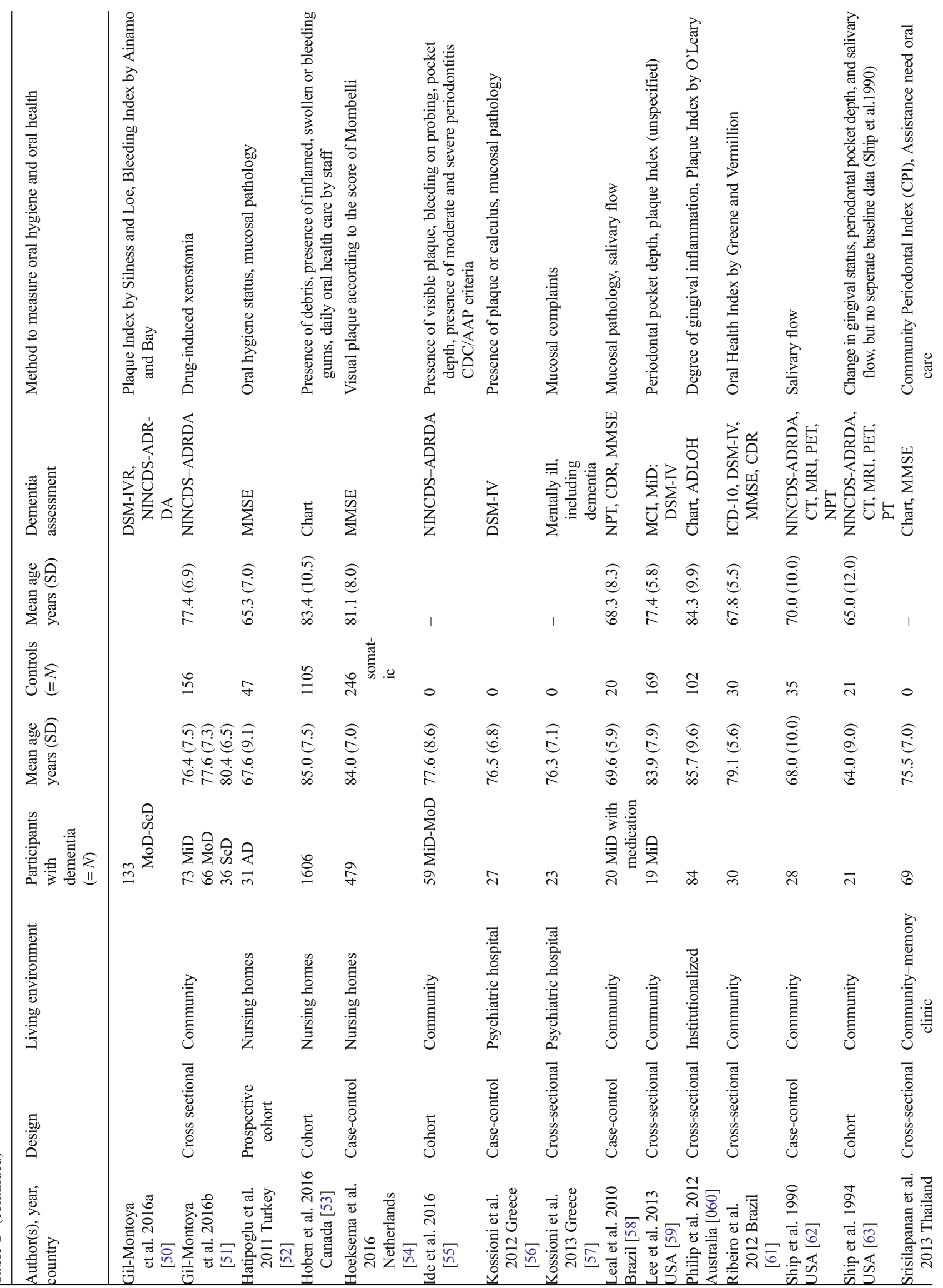




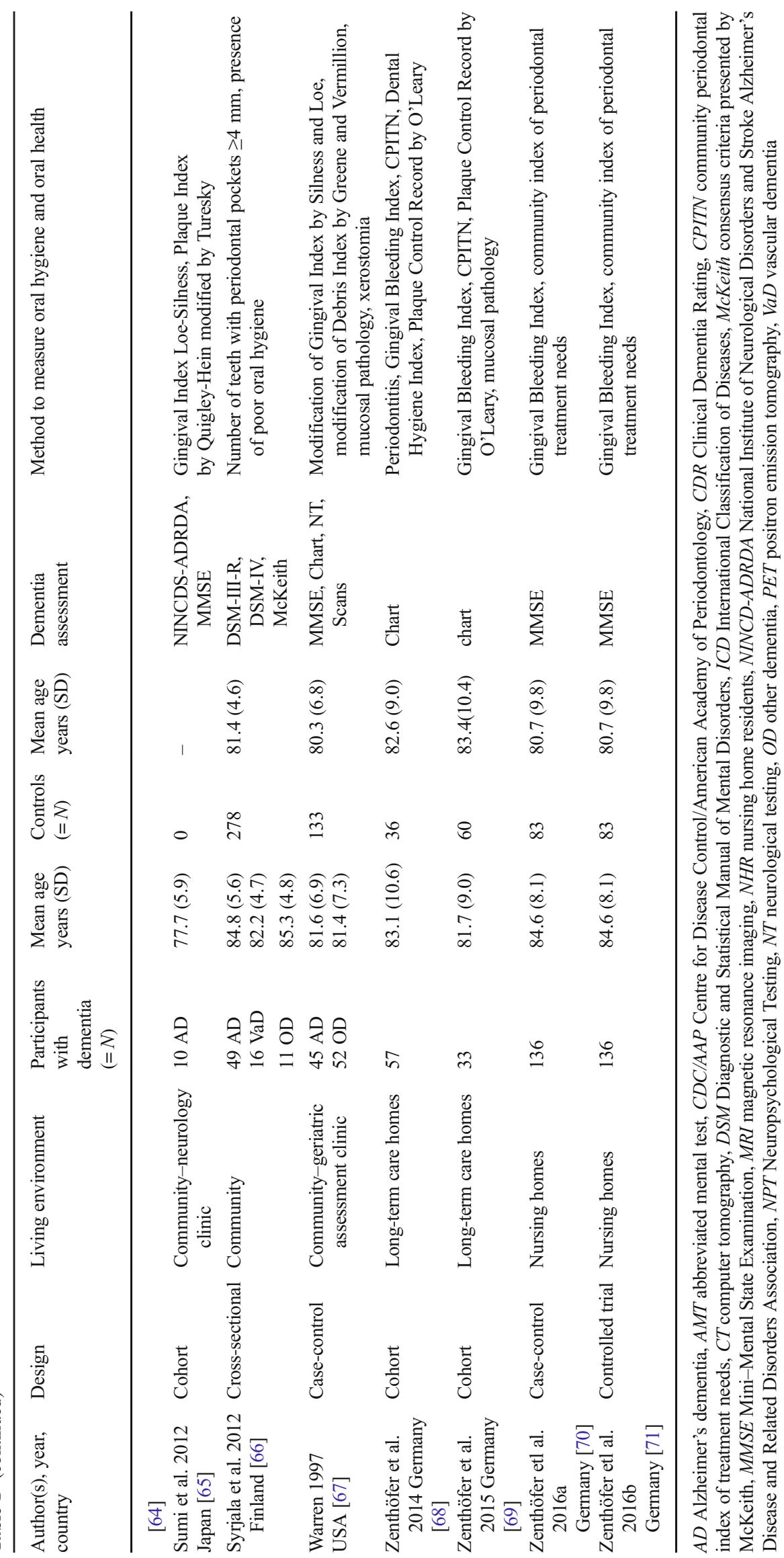




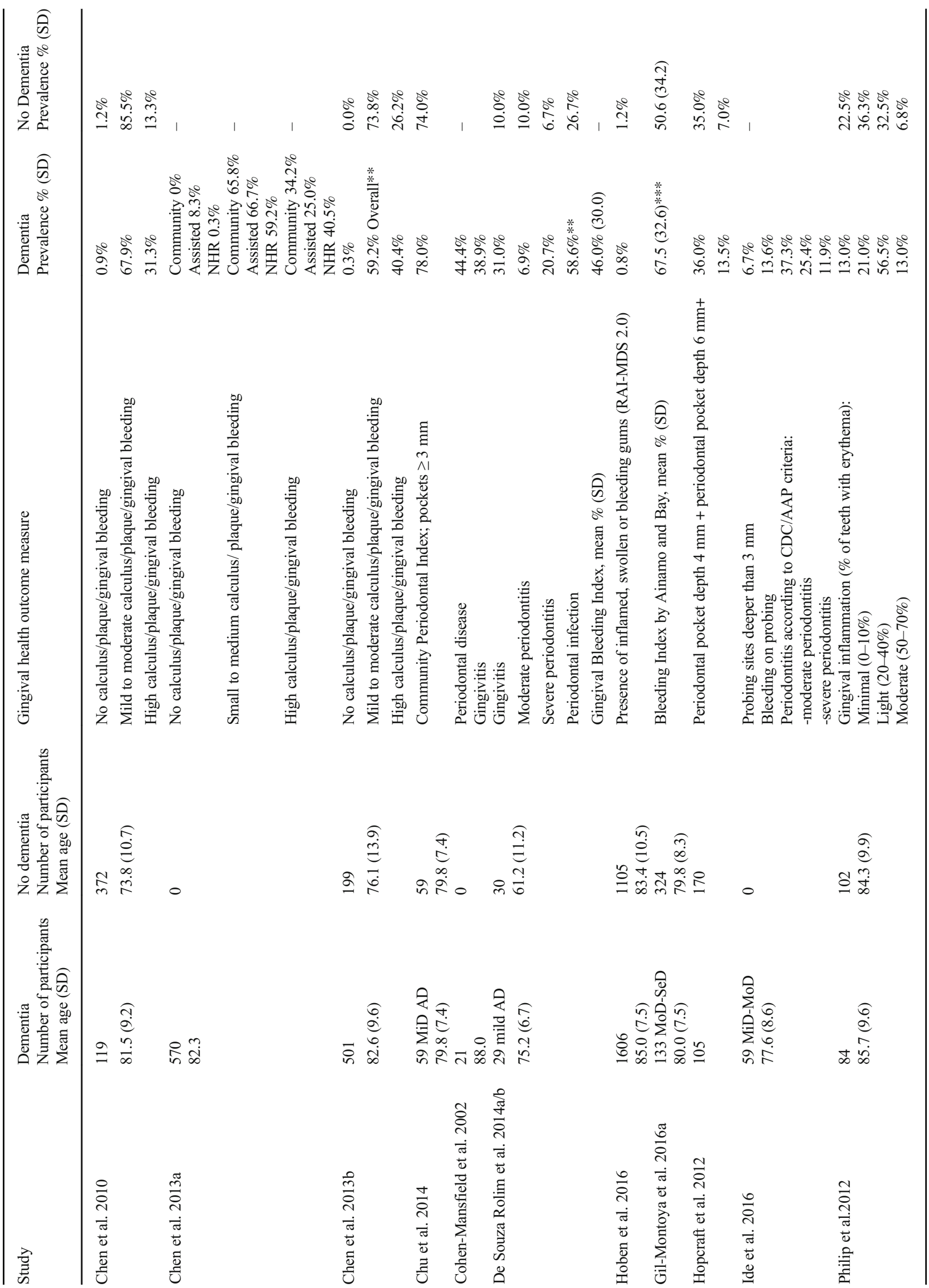




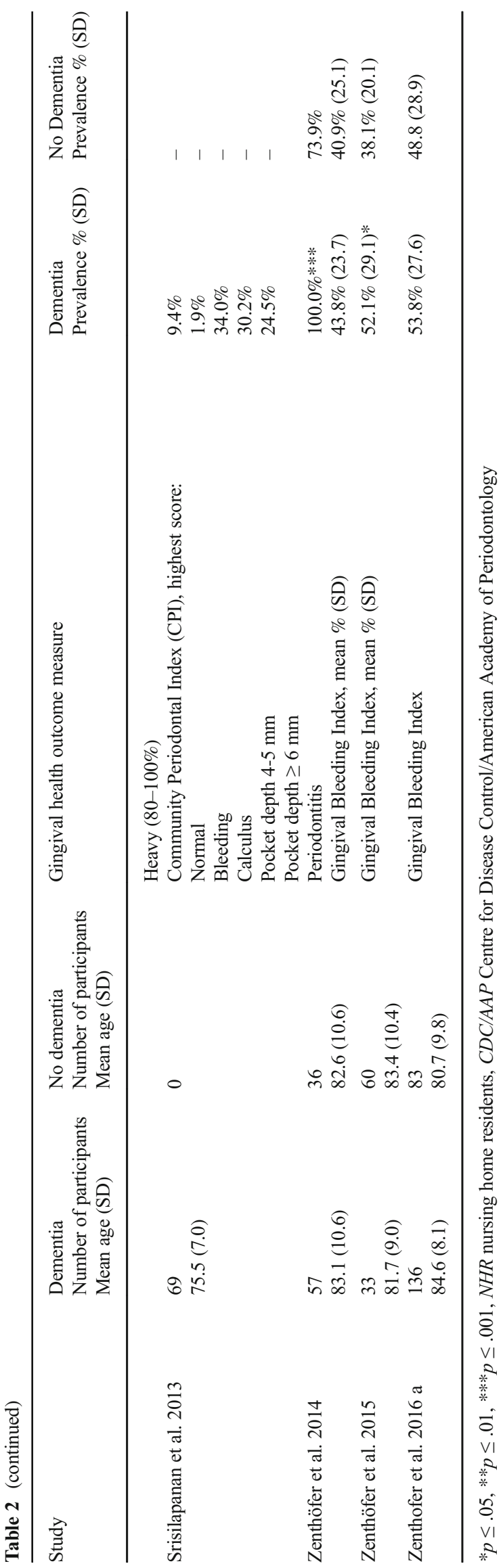

people without dementia. Studies including the Plaque Index by O'Leary found a mean percentage of 63.4 to $90.1 \%$ in participants with dementia $[46,60,68,76]$. Studies using the indices by Greene and Vermillion found a Debris Index of 2.1, a Calculus Index of 2.0, and an Oral Hygiene Index of 4.5 in participants with dementia $[36,49,61]$. The Plaque Index by Silness and Loe was 0.7 in a study by Chalmers et al. and 2.5 in a study by Gil Montoya et al. [38, 50]. Sumi et al. reported a Plaque Index by Quigley and Hein (modified by Turesky) of 1.6 in people with dementia [65].

When examining studies that compared oral hygiene in participants with and without dementia, nine studies found no significant differences $[36,38,52,53,59,60,66,75,76]$ and five studies found significantly more plaque in people with dementia $[48,50,61,67,68]$. Elsig et al. reported $100.0 \%$ visible plaque in participants with dementia and $36.0 \%$ in those without dementia [48]. Furthermore, a significantly higher O'Leary Plaque Index was found in participants with dementia (90.1\%), compared to participants without dementia (73.3\%) [68]. In addition, a significantly higher Oral Hygiene Index by Greene and Vermillion was found in participants with dementia (4.5) than in participants without dementia (2.2) [61]. A recent study found significantly more plaque with the Plaque Index of Silness and Loe in cases (2.5) than controls (1.6) [50].

Warren examined the Debris Index for dementia subtypes and severities and found no significant differences between dementia subtypes and controls, but found a significantly higher Debris Index in people with moderate to severe dementia, compared to people without dementia [67].

Studies about assistance need for oral care (Supplementary Table 3) reported a need of $21 \%$ and higher for both cleaning teeth and dentures in participants with dementia [38, 41, 42, 60, $64,72,75]$. Chalmers et al. reported a significantly higher need for assistance with oral hygiene care with an increasing severity of cognitive impairment [72]. In this study, the assistance need was $57.2 \%$ for cleaning teeth and $97.3 \%$ for cleaning dentures in people with moderate dementia, and $100.0 \%$ for cleaning teeth as well as dentures in people with severe dementia [72]. In all except 1 of 7 the comparing studies the assistance need for oral care or cleaning teeth and dentures was significantly higher in people with dementia than in those without [41, 42, 60, 72, 75].

\section{Oral pathology and oral dryness}

Candidiasis (Supplementary Table 4) was present in 3.6 to $30.0 \%$ of the cases, i.e., older people with dementia, and 0.0 to $5.0 \%$ of the controls, i.e., older people without dementia [44, 46, 47, 58]. The study by De Souza Rolim et al. (2014) found significantly more candidiasis in cases than in controls. Stomatitis was present in 18.1 to $59.1 \%$ of the cases and 0.0 to $7.4 \%$ of the controls $[38,52,56]$. The only study that compared stomatitis in cases and controls found significantly more stomatitis in cases than in controls [52]. 
Table 3 Indices (in means) of gingival and periodontal disease of older people with dementia, compared with older people without dementia

\begin{tabular}{|c|c|c|c|c|c|}
\hline Study & $\begin{array}{l}\text { Dementia } \\
\text { Number of } \\
\text { participants } \\
\text { Mean age (SD) }\end{array}$ & $\begin{array}{l}\text { No dementia } \\
\text { Number of } \\
\text { participants } \\
\text { Mean age (SD) }\end{array}$ & Gingival health outcome measure & $\begin{array}{l}\text { Dementia } \\
\text { Mean (SD) }\end{array}$ & $\begin{array}{l}\text { No } \\
\text { Dementia } \\
\text { Mean } \\
\text { (SD) }\end{array}$ \\
\hline \multirow{2}{*}{$\begin{array}{l}\text { De Souza Rolim et al. } \\
\text { 2014a }\end{array}$} & 29 mild $\mathrm{AD}$ & \multirow{2}{*}{$\begin{array}{l}30 \\
61.2(11.2)\end{array}$} & Probing pocket depth (in mm) & $1.6 \mathrm{~mm}(0.7)$ & - \\
\hline & $75.2(6.7)$ & & Clinical attachment level (in mm) & $2.9 \mathrm{~mm}(1.3)$ & - \\
\hline Ide et al. 2016 & $\begin{array}{l}59 \mathrm{MiD}-\mathrm{MoD} \\
77.6(8.6)\end{array}$ & 0 & Probing depth (in mm) & $2.5 \mathrm{~mm}(0.4)$ & - \\
\hline Lee et al. 2013 & $\begin{array}{l}19 \mathrm{MiD} \\
83.9(7.9)\end{array}$ & $\begin{array}{l}169 \\
77.4(5.8)\end{array}$ & Periodontal pocket depth (in mm) & $\begin{array}{l}\mathrm{MiD} 1.4 \mathrm{~mm} \\
\quad(1.1)\end{array}$ & $\begin{array}{c}1.5 \mathrm{~mm} \\
(1.2)\end{array}$ \\
\hline Sumi et al. 2012 & $\begin{array}{l}10 \\
77.7(5.9)\end{array}$ & 0 & Gingival Index Loe-Silness (index score) & 1.2 & - \\
\hline Syrjala et al.2012 & $\begin{array}{l}49 \mathrm{AD} \\
84.8(5.6) \\
16 \mathrm{VaD} \\
82.2(4.7) \\
11 \mathrm{OD} \\
85.3(4.8)\end{array}$ & $\begin{array}{l}278 \\
81.4(4.6)\end{array}$ & Number of teeth with periodontal pockets $\geq 4 \mathrm{~mm}$ & $\begin{array}{l}\text { AD } 2.8(3.3) \\
\text { VaD } 2.8(3.8) \\
\text { OD } 1.7(1.5)\end{array}$ & $2.9(3.8)$ \\
\hline Warren et al. 1997 & $\begin{array}{l}45 \mathrm{AD} \\
81.6(6.9) \\
52 \mathrm{OD} \\
81.4(7.3)\end{array}$ & $\begin{array}{l}133 \\
80.3(6.8)\end{array}$ & $\begin{array}{l}\text { Modified version of the Gingival Index by Silness and } \\
\text { Loe (index score) }\end{array}$ & $\begin{array}{l}\text { AD } 1.1(0.8)^{*} \\
\text { OD } 0.9(0.7)\end{array}$ & $0.7(0.6)$ \\
\hline Zenthöfer et al. 2014 & $\begin{array}{l}57 \\
83.1(10.6)\end{array}$ & $\begin{array}{l}36 \\
82.6(10.6)\end{array}$ & $\begin{array}{l}\text { Community periodontal index of treatment needs (index } \\
\text { score) }\end{array}$ & $3.4(0.5)^{* * *}$ & $2.8(0.6)$ \\
\hline Zenthöfer et al. 2015 & $\begin{array}{l}33 \\
81.7(9.0)\end{array}$ & $\begin{array}{l}60 \\
83.4(10.4)\end{array}$ & $\begin{array}{l}\text { Community periodontal index of treatment needs (index } \\
\text { score) }\end{array}$ & $3.3(0.6)$ & $3.1(0.6)$ \\
\hline Zenthofer et al. $2016 \mathrm{a}, \mathrm{b}$ & $\begin{array}{l}136 \\
84.6(8.1)\end{array}$ & $\begin{array}{l}83 \\
80.7(9.8)\end{array}$ & $\begin{array}{l}\text { Community periodontal index of treatment needs (index } \\
\text { score) }\end{array}$ & $3.1(0.7)^{* * *}$ & $2.7(0.6)$ \\
\hline
\end{tabular}

${ }^{*} p \leq .05, * * p \leq .01, * * * p \leq .001, A D$ Alzheimer's dementia, Mid mild dementia, $N D$ no dementia, $O D$ other dementia's, VaD vascular dementia

Xerostomia (Supplementary Table 4), i.e., a subjective feeling of a dry mouth, was present in 9.1 to $45.0 \%$ of the cases and 8.4 to $20.0 \%$ of the controls [57, 58, 67, ]. Warren et al. found significantly more xerostomia in people with dementia subtypes other than Alzheimer's disease (22.0\%) than in people without dementia (8.4\%) in their clinician assessment of xerostomia. In addition, xerostomia was found in $9.1 \%$ of the people with Alzheimer's disease in this study [67]. A recent study found significantly more drug-induced xerostomia in cases (68.5-72.2\%) than in controls (36.5\%) [51].

In addition, various studies indicated that people without dementia have significantly more unstimulated salivary flow (Supplementary Table 5) than people with dementia [39, 44, 58]. One study indicated that people without dementia have more stimulated submandibular flow than Alzheimer's disease [39]. The study of Leal et al. (2010) showed the buffering capacity is higher in people without dementia and without medication than in people with dementia and medication [58].

\section{Discussion}

The main aim of this study was to provide a comprehensive overview with critical appraisal of studies concerning the health of oral soft tissues and oral hygiene in older people with dementia. The additional aim was to compare oral health of older people with and without dementia. The studies included in this review suggest that older people with dementia have much plaque and many oral health problems related to oral soft tissues, such as gingival bleeding, periodontal pockets, stomatitis, mucosal lesions, and reduced salivary flow.

While oral health in people with dementia is poor [42, 66, 68], the subtype of dementia, e.g., Alzheimer's disease, vascular dementia, does not seem to be an essential determinant of oral health $[38,66,67]$. However, the severity of cognitive decline does seem to play a role in the oral health of older people with dementia, with more plaque and oral disease in people with more cognitive decline $[36,38,66,67,72]$. An exception to this finding is the study of Srisilapanan et al. [64], which was explained by the fact that people visiting the memory clinic in this study also got dental treatment with every visit. The people included in this study had better access to oral care compared to the general population. In addition, living environment, e.g., nursing home, community, might play a role in the oral health of older people with dementia $[61,72]$. Some studies found no significant differences between living environments, but a poor oral health in people with dementia, regardless of residency [38, 41]. Some studies found more problems in nursing home residents compared to community 
Table 4 Oral hygiene measures (in percentages) of older people with dementia, compared with older people without dementia

\begin{tabular}{|c|c|c|c|c|c|}
\hline Study & $\begin{array}{l}\text { Dementia } \\
\text { Number of } \\
\text { participants } \\
\text { Mean age (SD) }\end{array}$ & $\begin{array}{l}\text { No dementia } \\
\text { Number of } \\
\text { participants } \\
\text { Mean age (SD) }\end{array}$ & Oral hygiene outcome measure & $\begin{array}{l}\text { Dementia } \\
\text { Prevalence \% } \\
(\mathrm{SD})\end{array}$ & $\begin{array}{l}\text { No dementia } \\
\text { Prevalence } \% \\
\text { (SD) }\end{array}$ \\
\hline Chapman et al. 1991 & $\begin{array}{l}85 \mathrm{AD} \\
74.9\end{array}$ & - & $\begin{array}{l}\text { Soft deposits } \\
\text { Hard deposits } \\
\text { Unsatisfactory level of oral hygiene }\end{array}$ & $\begin{array}{l}70.0 \% \\
60.0 \% \\
90.0 \%\end{array}$ & - \\
\hline $\begin{array}{l}\text { De Souza Rolim et al. } 2014 \\
\text { a, b }\end{array}$ & $\begin{array}{l}29 \text { mild } \mathrm{AD} \\
75.2(6.7)\end{array}$ & $\begin{array}{l}30 \\
61.2(11.2)\end{array}$ & Plaque Index by O’Leary, mean \% (SD) & $73.6 \%(5.7)$ & - \\
\hline Elsig et al. 2013 & $\begin{array}{l}29 \\
82.5(6.3)\end{array}$ & $\begin{array}{l}22 \\
81.9(6.5)\end{array}$ & Presence of visible dental plaque & $100.0 \% * *$ & $36.0 \%$ \\
\hline Hatipoglu et al. 2011 & $\begin{array}{l}31 \mathrm{AD} \\
67.6(9.1)\end{array}$ & $\begin{array}{l}47 \\
65.3(7.0)\end{array}$ & $\begin{array}{l}\text { Good oral hygiene } \\
\text { Fair oral hygiene } \\
\text { Poor oral hygiene }\end{array}$ & $\begin{array}{l}3.2 \% \\
29.0 \% \\
67.7 \%\end{array}$ & $\begin{array}{l}19.1 \% \\
31.9 \% \\
48.9 \%\end{array}$ \\
\hline Hoben et al. 2016 & $\begin{array}{l}1606 \\
85.0(7.5)\end{array}$ & $\begin{array}{l}1105 \\
83.4(10.5)\end{array}$ & Presence of debris (RAI-MDS 2.0) & $9.8 \%$ & $11.4 \%$ \\
\hline Hoeksema et al. 2016 & $\begin{array}{l}103 \\
80.8(7.5)\end{array}$ & $\begin{array}{l}49 \text { somatic } \\
78.1(7.9)\end{array}$ & Poor oral hygiene (Mombelli score 2 or 3 ) & $72.8 \%$ & $77.6 \%$ \\
\hline Hopcraft et al. 2012 & 105 & 170 & $\begin{array}{l}\text { Thin band of visual plaque } \\
<1 / 3 \text { tooth with visual plaque } \\
>1 / 3 \text { tooth with visual plaque }\end{array}$ & $\begin{array}{l}26.3 \% \\
43.4 \% \\
30.3 \%\end{array}$ & $\begin{array}{l}36.5 \% \\
38.4 \% \\
25.2 \%\end{array}$ \\
\hline Ide et al. 2016 & $\begin{array}{l}59 \text { MiD-MoD } \\
77.6(8.6)\end{array}$ & 0 & $\begin{array}{l}\text { Detectable plaque: } \\
\text {-without a dental probe } \\
\text {-with a dental probe }\end{array}$ & $\begin{array}{l}89.0 \%(12.5) \\
19.9 \%(11.8) \\
69.1 \%(20.6)\end{array}$ & - \\
\hline Kossioni et al. 2012 & $\begin{array}{l}27 \\
76.5(6.8)\end{array}$ & - & Presence of plaque or calculus & $80.0 \%$ & - \\
\hline Philip et al. 2012 & $\begin{array}{l}84 \\
85.7(9.6)\end{array}$ & $\begin{array}{l}102 \\
84.3(9.9)\end{array}$ & Plaque Index by O’Leary, mean \% (SD) & $63.4 \%(35.7)$ & $54.5(35.7)$ \\
\hline Syrjala et al. 2012 & $\begin{array}{l}49 \operatorname{AD} 84.8(5.6) \\
16 \operatorname{VaD} 82.2(4.7) \\
11 \text { OD } 85.3(4.8)\end{array}$ & $\begin{array}{l}278 \\
81.4(4.6)\end{array}$ & Presence of poor oral hygiene & $\begin{array}{l}\text { AD } 77.8 \% \\
\text { VaD } 60.0 \% \\
\text { OD } 66.7 \%\end{array}$ & $36.6 \%$ \\
\hline Zenthöfer et al. 2014 & $\begin{array}{l}57 \\
83.1(10.6)\end{array}$ & $\begin{array}{l}36 \\
82.6(10.6)\end{array}$ & $\begin{array}{l}\text { Plaque Control Record by O'Leary, mean } \\
\% \text { (SD) }\end{array}$ & $90.1 \%(13.1)^{* *}$ & $73.3 \%(25.1)$ \\
\hline Zenthöfer et al. 2015 & $\begin{array}{l}33 \\
81.7(9.0)\end{array}$ & $\begin{array}{l}60 \\
83.4(10.4)\end{array}$ & $\begin{array}{l}\text { Plaque Control Record by O’Leary, mean } \\
\% \text { (SD) }\end{array}$ & $89.3 \%(12.6)$ & $80.3 \%(23.0)$ \\
\hline
\end{tabular}

$* p \leq .05, * * p \leq .01, * * * p \leq .001, A D$ Alzheimer's dementia, $O D$ other dementia's, $V a D$ vascular dementia

living elderly $[61,72]$. This can be explained by a higher degree of cognitive and functional impairment in the nursing home population [41].

The deterioration of cognitive functions, such as executive functioning, working memory, attention, and apraxia, complicates the ability to perform oral care in people with dementia [42], which results in more plaque $[60,68]$. Furthermore, functional changes in dementia, like declined hand grip strength and motor skills, can complicate oral care $[52,61]$. Dental plaque is the primary cause of gingivitis and subsequently periodontitis [77]. Therefore, with a high amount of plaque in older people with dementia in the evaluated articles, a high amount of gingivitis and periodontitis could be expected. Periodontitis has been associated with multiple systemic health conditions (mainly diabetes mellitus type 2 and cardiovascular disease) [4]. Therefore, treatment of periodontitis is important to reduce systemic health risks.

Recently, the association between oral health and cognitive decline was systematically reviewed. The authors concluded that the association was still unclear [18, 19].
Within the included papers, salivary function appeared to be intact in the healthy aging sample. However, objective (hyposalivation) or subjective (xerostomia) dry mouth is more likely to be present in older people with medication use, history of radiotherapy in the head and neck region, and autoimmune disease, such as Sjögren syndrome $[5,11,78]$. In addition, people with Alzheimer's disease have significantly lower stimulated submandibular and unstimulated salivary flow rate [39, 44, 58]. This might be explained by neuropathological changes characteristic for Alzheimer's disease, leading to changes in the autonomic nervous system $[39,44]$.

\section{Critical appraisal}

The NOS comprises five categories concerning a control group, which means studies without control group consequently receive a lower score. Six of the 14 included studies with cross-sectional design did not have a control group and therefore had a NOS score 
Table 5 Oral hygiene indices (in means) of older people with dementia compared with older people without dementia

\begin{tabular}{|c|c|c|c|c|c|}
\hline Study & $\begin{array}{l}\text { Dementia } \\
\text { Number of } \\
\text { participants } \\
\text { Mean age (SD) }\end{array}$ & $\begin{array}{l}\text { No dementia } \\
\text { Number of } \\
\text { participants } \\
\text { Mean age (SD) }\end{array}$ & Oral hygiene outcome measure & $\begin{array}{l}\text { Dementia } \\
\text { Mean (SD) }\end{array}$ & $\begin{array}{l}\text { No dementia } \\
\text { Mean (SD) }\end{array}$ \\
\hline \multirow[t]{2}{*}{ Adam et al. 2006} & $\begin{array}{l}81 \mathrm{MoD}-\mathrm{SeD} \\
80.8(7.6)\end{array}$ & $\begin{array}{l}\text { 54 ND-MiD } \\
85.5(7.6)\end{array}$ & Debris Index by Greene and Vermillion & $\begin{array}{l}\mathrm{MoD} / \mathrm{SeD} 2.1 \\
\quad(0.7)\end{array}$ & $\begin{array}{l}\mathrm{ND} / \mathrm{MiD} 1.3 \\
\quad(0.6)\end{array}$ \\
\hline & & & Calculus Index by Greene and Vermillion & $\begin{array}{l}\mathrm{MoD} / \mathrm{SeD} 2.0 \\
\quad(0.8)\end{array}$ & $\begin{array}{l}\mathrm{ND} / \mathrm{MiD} 1.3 \\
(0.6)\end{array}$ \\
\hline $\begin{array}{l}\text { Chalmers et al. } \\
2003\end{array}$ & $\begin{array}{l}116 \\
<79 \text { years: } 91 \\
80+\text { years: } 25\end{array}$ & $\begin{array}{l}116 \\
<79 \text { years: } 91 \\
80 \text { + years: } 25\end{array}$ & Plaque Index by Silness and Loe & 0.7 (mv) & $0.6(\mathrm{mv})$ \\
\hline $\begin{array}{l}\text { Gil-Montoya et al. } \\
2016\end{array}$ & $\begin{array}{l}133 \mathrm{MoD}-\mathrm{SeD} \\
80.0(7.5)\end{array}$ & $\begin{array}{l}324 \\
79.8(8.3)\end{array}$ & Plaque Index by Silness and Loe & $2.5(0.6)^{* * *}$ & $1.6(0.9)$ \\
\hline $\begin{array}{l}\text { Hoeksema et al. } \\
2016\end{array}$ & $\begin{array}{l}103 \\
80.8(7.5)\end{array}$ & $\begin{array}{l}49 \text { somatic } \\
78.1(7.9)\end{array}$ & Visual plaque score Mombelli & $2.1(0.9)$ & $2.3(0.9)$ \\
\hline Lee et al. 2013 & $\begin{array}{l}19 \\
83.9(7.9)\end{array}$ & $\begin{array}{l}169 \\
77.4(5.8)\end{array}$ & Plaque Index (unspecified) & MiD $0.9(0.7)$ & $0.5(0.6)$ \\
\hline Ribeiro et al. 2012 & $\begin{array}{l}30 \\
79.1(5.6)\end{array}$ & $\begin{array}{l}30 \\
67.8(5.5)\end{array}$ & Oral Hygiene Index by Greene and Vermillion & $4.5(1.7-10.0)^{* *}$ & $2.2(0.3-8.0)$ \\
\hline Sumi et al. 2012 & $\begin{array}{l}10 \\
77.7(5.9)\end{array}$ & 0 & $\begin{array}{l}\text { Plaque Index by Quigley-Hein (modified by } \\
\text { Turesky) }\end{array}$ & 1.6 & - \\
\hline Warren et al. 1997 & $\begin{array}{l}45 \text { AD } 81.6(6.9) \\
52 \text { OD } 81.4(7.3)\end{array}$ & $\begin{array}{l}133 \\
80.3(6.8)\end{array}$ & $\begin{array}{l}\text { Modification of the Debris Index by Greene and } \\
\text { Vermillion }\end{array}$ & $\begin{array}{l}\text { AD } 1.0(0.8) \\
\text { OD } 1.0(0.8) \\
\text { MiD } 1.0(0.7) \\
\text { MoD-SeD } 1.1 \\
(0.9)^{*}\end{array}$ & $0.8(0.6)$ \\
\hline
\end{tabular}

$* p \leq .05, * * p \leq .01, * * * p \leq .001, A D$ Alzheimer's dementia, MiD mild dementia, $M o D$ moderate dementia, $N D$ no dementia, $O D$ other dementia's, $S e D$ severe dementia, $\mathrm{VaD}$ vascular dementia

below the median score of 5. Consequently, for the studies without a control group, it was not possible to compare older people with and without dementia. Furthermore, most of the included studies did not describe the non-response rate and consequently lacked a point on the NOS for this category. An issue worth mentioning, is that for the data-extraction of this review only baseline data was used, while the NOS also includes two items concerning follow-up studies for cohort studies. These two follow-up items in the 10 included cohort studies are not relevant for this review, but might be of interest for further appraisal of the studies.

\section{Strengths and limitations}

The main strengths of this review are the critical appraisal of the articles, the summary tables of the dementia and oral health variables, and the involvement of a multidisciplinary team. Concerning the critical appraisal, most studies demonstrated good representativeness of older people with dementia, and almost all included studies followed a standardized structured dental examination by a dentist. The involvement of the multidisciplinary team critically evaluated the dental, neuropsychological, medical, ethical, and methodological aspects of this study.
Limitations of this review are the following: the included studies used a broad range of outcome measures, most studies had a cross-sectional design, and the number of studies with a NOS score below 5 was considerable. However, if these studies would have been excluded, the tendency of the results for the group of older people with dementia would have remained the same. It was therefore decided to keep the studies with a NOS score below 5 in the overview of the results. In addition, the methodological and clinical heterogeneity between the studies was considered too large to perform a meta-analysis. Furthermore, many of the included studies did not use a formal dementia diagnosis or diagnostic instruments, but screening instruments for cognition. In these studies, it might be more appropriate to address to the participants as people with cognitive impairment instead of people with dementia. In addition, the non-response rate was rarely described, which complicates the assessment of potential selection-bias.

\section{Implications and clinical suggestions}

In order to improve the oral health of older people with dementia, oral health assessment tools, oral hygiene care 
strategies, and guidelines should be used [79-83]. To maintain good oral health, daily removal of dental plaque by brushing the teeth is essential [84]. Therefore, oral hygiene care for dependent people should be in the daily activities of care $[81,85]$ and oral health care education might improve the knowledge and attitude of caretakers [86]. Although providing oral care and dental treatment can be complicated by challenging behavior, strategies that approach it as threat perception might help the well-being of people with dementia [87]. Regular assessment of the oral health should take place by caretakers, as well as dentists [81]. An oral health assessment tool can be used to identify risk factors and should consist of intra-oral examination, observation of behavior, and (if possible) an evaluation of the client perception of treatment need [82, 88]. For oral care, treatment planning, and behavioral management for people with dementia, the level of cognitive impairment and cooperation of the patient, as well as the input from the multi-disciplinary team of health care professionals, and formal and informal caretakers should be taken into account $[17,89]$.

\section{Future research}

For future research, it is suggested to use a formal diagnosis for dementia [90]. If neuropsychological testing is no longer possible, a short cognitive screening instrument, such as the Mini-Mental State Examination (MMSE), can be used to get an impression of the level of cognitive functioning [91]. However, a low score on the MMSE is only an indication of cognitive impairment and does not replace the diagnostic examination required for a dementia diagnosis [92].

For the oral health assessment in older people with dementia, an international, standardized method can be useful. Although the manual WHO Oral Health Survey Basic Methods provides no information on assessing the oral health status of older people with dementia [93], guidelines for oral health care for institutionalized older people do exist $[81,82$, 94].

\section{Conclusion}

The studies included in the current systematic review suggest that older people with dementia have high levels of plaque and many oral health problems related to oral soft tissues, such as gingival bleeding, periodontal pockets, stomatitis, mucosal lesions, and reduced salivary flow.

The oral hygiene and oral health of older people with dementia should be improved. This could be achieved by oral care education of formal and informal caregivers, the use of oral health screening tools, and regular professional dental care for people with dementia.
Acknowledgements We thank Dr. Eiko Yoshida of the Tokyo Medical and Dental University (TMDU), Tokyo, Japan for her help with the assessment of the Japanese articles. We thank Prof. Dr. Fridus van der Weijden of the Department of Periodontology of the Academic Centre for Dentistry Amsterdam, Amsterdam, The Netherlands for his valuable comments on our manuscript.

We thank Dr. Knute Carter, College of Public Health, University of Iowa in the United States of America, Dr. Chen, the University of North Carolina in the United States of America, Dr. Del Brutto, Universidad Espíritu Santo in Ecuador, Dr. Fjeld, University of Oslo in Norway, Dr. Gil Montoya of the University of Granada in Spain, Dr. Hoben from the University of Alberta in Canada, Dr. Hoeksema of the University of Groningen in the Netherlands, Dr. Hege Kersten, associated professor at the University of Oslo and head of research at Telemark Hospital Trust in Norway, Dr. Lee, Boston College in the United States of America, Prof. Dr. Pivetta Roque, Fluminense Federal University in Brazil, and Dr. Skoog, University of Gothenburg in Sweden for their responses to our requests for additional information about their articles.

Funding The work was supported by Alzheimer Nederland, Amstelring, Fonds NutsOhra, Roomsch Catholijk Oude Armen Kantoor (RCOAK), Stichting Beroepsopleiding Huisartsen (SBOH), and Stichting Henriëtte Hofje.

\section{Compliance with ethical standards}

Conflict of interest The authors declare that they have no conflict of interest.

Ethical approval This is a review of literature and does not require ethical approval.

Informed consent For this type of study, formal consent is not required.

Open Access This article is distributed under the terms of the Creative Commons Attribution 4.0 International License (http:// creativecommons.org/licenses/by/4.0/), which permits unrestricted use, distribution, and reproduction in any medium, provided you give appropriate credit to the original author(s) and the source, provide a link to the Creative Commons license, and indicate if changes were made.

\section{References}

1. United Nations, Department of Economic and Social Affairs PD (2013) World Population Ageing 2013. World Popul Ageing 2013 114. ST/ESA/SER.A/348

2. Rodríguez-Rodero S, Fernández-Morera JL, Menéndez-Torre E et al (2011) Aging genetics and aging. Aging Dis 2:186-195

3. Lee Y-T, Lee H-C, Hu C-J et al (2016) Periodontitis as a modifiable risk factor for dementia: a nationwide populationbased cohort study. J Am Geriatr Soc. https://doi.org/10.1111/ jgs. 14449

4. Otomo-Corgel J, Pucher JJ, Rethman MP, Reynolds MA (2012) State of the science: chronic periodontitis and systemic health. J Evid Based Dent Pract 12:20-28. https://doi.org/10.1016/S15323382(12)70006-4

5. Gonsalves WC, Wrightson AS, Henry RG (2008) Common oral conditions in older persons. Am Fam Physician 78:845-852

6. Petersen PE, Yamamoto T (2005) Improving the oral health of older people: the approach of the WHO Global Oral Health Programme. Community Dent Oral Epidemiol 33:81-92. https://doi.org/10. 1111/j.1600-0528.2004.00219.x 
7. Petersen PE (2003) The World Oral Health Report 2003: continuous improvement of oral health in the 21st century - the approach of the WHO Global Oral Health Programme. Community Dent Oral Epidemiol 31:3-24. https://doi.org/10.1046/j.2003.com122.x

8. Thomson WM (2004) Dental caries experience in older people over time: what can the large cohort studies tell us? Br Dent J 196:89-92; discussion 87. https://doi.org/10.1038/sj.bdj.4810900

9. Boehm TK, Scannapieco FA (2007) The epidemiology, consequences and management of periodontal disease in older adults. $\mathrm{J}$ Am Dent Assoc 138 Suppl:26S-33S. doi: 10.14219/jada.archive. 2007.0360

10. Affoo RH, Foley N, Garrick R et al (2015) Meta-analysis of salivary flow rates in young and older adults. J Am Geriatr Soc 63: 2142-2151. https://doi.org/10.1111/jgs.13652

11. Ship JA, Pillemer SR, Baum BJ (2002) Xerostomia and the geriatric patient. J Am Geriatr Soc 50:535-543

12. Warnakulasuriya S (2009) Global epidemiology of oral and oropharyngeal cancer. Oral Oncol 45:309-316. https://doi.org/10.1016/j. oraloncology.2008.06.002

13. Ewan V, Staines K (2008) Diagnosis and management of oral mucosal lesions in older people: a review. Rev Clin Gerontol 18:115. https://doi.org/10.1017/S0959259809002767

14. Kandelman D, Petersen PE, Ueda H (2008) Oral health, general health, and quality of life in older people. Spec Care Dentist 28: 224-236. https://doi.org/10.1111/j.1754-4505.2008.00045.x

15. Locker D (1992) The burden of oral disorders in a population of older adults. Community Dent Health 9:109-124

16. Brennan LJ, Strauss J (2014) Cognitive impairment in older adults and oral health considerations: treatment and management. Dent Clin North Am 58:815-828. https://doi.org/10.1016/j.cden.2014. 07.001

17. Ghezzi EM, Ship JA (2000) Dementia and oral health. Oral Surg Oral Med Oral Pathol Oral Radiol Endod 89:2-5

18. Wu B, Fillenbaum GG, Plassman BL, Guo L (2016) Association between oral health and cognitive status: a systematic review. J Am Geriatr Soc 64:739-751. https://doi.org/10.1111/jgs.14036

19. Tonsekar PP, Jiang SS, Yue G (2017) Periodontal disease, tooth loss and dementia: is there a link? A systematic review. Gerodontology 34:151-163. https://doi.org/10.1111/ger.12261

20. Arrivé E, Letenneur L, Matharan F et al (2012) Oral health condition of French elderly and risk of dementia: a longitudinal cohort study. Community Dent Oral Epidemiol 40:230-238. https://doi. org/10.1111/j.1600-0528.2011.00650.x

21. Batty G-D, Li Q, Huxley R et al (2013) Oral disease in relation to future risk of dementia and cognitive decline: prospective cohort study based on the action in diabetes and vascular disease: Preterax and Diamicron Modified-Release Controlled Evaluation (ADVANCE) trial. Eur Psychiatry 28:49-52. https://doi.org/10. 1016/j.eurpsy.2011.07.005

22. Paganini-Hill A, White SC, Atchison KA (2012) Dentition, dental health habits, and dementia: the leisure world cohort study. J Am Geriatr Soc 60:1556-1563. https://doi.org/10.1111/j.1532-5415. 2012.04064.x

23. Shimazaki Y, Soh I, Saito T et al (2001) Influence of dentition status on physical disability, mental impairment, and mortality in institutionalized elderly people. J Dent Res 80:340-345. https://doi.org/ 10.1177/0022034501080001080

24. Stein PS, Desrosiers M, Donegan SJ, et al (2007) Tooth loss, dementia and neuropathology in the Nun study. J Am Dent Assoc 138:1314-22-2

25. Stein PS, Kryscio RJ, Desrosiers M et al (2010) Tooth loss, apolipoprotein E, and decline in delayed word recall. J Dent Res 89:473477. https://doi.org/10.1177/0022034509357881

26. Stewart R, Stenman U, Hakeberg M et al (2015) Associations between oral health and risk of dementia in a 37-year follow-up study: the prospective population study of women in Gothenburg. J Am Geriatr Soc 63:100-105. https://doi.org/10.1111/jgs.13194

27. Yamamoto T, Kondo K, Hirai H et al (2012) Association between self-reported dental health status and onset of dementia: a 4-year prospective cohort study of older Japanese adults from the Aichi Gerontological Evaluation Study (AGES) project. Psychosom Med 74:241-248. https://doi.org/10.1097/PSY.0b013e318246dffb

28. Delwel S, Binnekade TT, Perez RSGM et al (2017) Oral health and orofacial pain in older people with dementia: a systematic review with focus on dental hard tissues. Clin Oral Investig 21:17-32. https://doi.org/10.1007/s00784-016-1934-9

29. Liberati A, Altman DG, Tetzlaff J et al (2009) The PRISMA statement for reporting systematic reviews and meta-analyses of studies that evaluate health care interventions: explanation and elaboration. J Clin Epidemiol 62:e1-34. https://doi.org/10.1016/j.jclinepi.2009.06.006

30. Wells GA, Shea B, O'Connell D, Petersen J, Welch V, Losos MTP The Newcastle-Ottawa scale (NOS) for assessing the quality of nonrandomized studies in meta-analyses. In: Dep. Epidemiol. Community med. Univ. Ottawa. Can Underwrit http://www.ohri. ca/programs/clinical_epidemiology/oxford.htm

31. Verhagen AP, De Vet HCW, De Bie RA et al (1998) The Delphi list: A criteria list for quality assessment of randomized clinical trials for conducting systematic reviews developed by Delphi consensus. J Clin Epidemiol 51:1235-1241. https://doi.org/10.1016/S08954356(98)00131-0

32. American Psychiatric Association (2000) Diagnostic and statistical manual of mental disorders, 3rd edn. Fourth Edition, Text Revision (DSM-IV-TR. https://doi.org/10.1176/appi.books.9780890423349

33. World Health Organization (2008) ICD-10 International Statistical Classification of Diseases and Related Health Problems. WHO Libr. Cat. In: Data 2

34. McKhann G, Drachman D, Folstein M et al (1984) Clinical diagnosis of Alzheimer's disease: report of the NINCDS-ADRDA work group under the auspices of Department of Health and Human Services Task Force on Alzheimer's disease. Neurology 34:939 944. https://doi.org/10.1212/WNL.34.7.939

35. McKhann GM, Knopman DS, Chertkow H et al (2011) The diagnosis of dementia due to Alzheimer's disease: recommendations from the National Institute on Aging-Alzheimer's association workgroups on diagnostic guidelines for Alzheimer's disease. Alzheimers Dement 7:263-269. https://doi.org/10.1016/j.jalz.2011.03.005

36. Adam H, Preston AJ (2006) The oral health of individuals with dementia in nursing homes. Gerodontology 23:99-105. https:// doi.org/10.1111/j.1741-2358.2006.00118.x

37. Chalmers JM, Carter KD, Spencer AJ (2002) Caries incidence and increments in community-living older adults with and without dementia. Gerodontology 19:80-94. https://doi.org/10.1111/j.17412358.2002.00080.x

38. Chalmers JM, Carter KD, Spencer AJ (2003) Oral diseases and conditions in community-living older adults with and without dementia. Spec Care Dentist 23:7-17. https://doi.org/10.1111/j.17544505.2003.tb00283.x

39. Chapman PJ, Shaw RM (1991) Normative dental treatment needs of Alzheimer patients. Aust Dent J 36:141-144. https://doi.org/10. 1111/j.1834-7819.1991.tb01343.x

40. Chen X, Shuman SK, Hodges JS et al (2010) Patterns of tooth loss in older adults with and without dementia: a retrospective study based on a Minnesota cohort. J Am Geriatr Soc 58:2300-2307. https://doi.org/10.1111/j.1532-5415.2010.03192.x

41. Chen X, Clark JJJ, Naorungroj S (2013) Oral health in older adults with dementia living in different environments: a propensity analysis. Spec Care Dentist 33:239-247. https://doi.org/10.1111/scd. 12006

42. Chen X, Clark JJJ, Naorungroj S (2013) Oral health in nursing home residents with different cognitive statuses. Gerodontology 30:49-60. https://doi.org/10.1111/j.1741-2358.2012.00644.x 
43. Chen X, Clark JJ, Chen H, Naorungroj S (2015) Cognitive impairment, oral self-care function and dental caries severity in community-dwelling older adults. Gerodontology 32:53-61. https://doi.org/10.1111/ger.12061

44. Chu CH, Ng A, Chau AMH, Lo ECM (2015) Oral health status of elderly Chinese with dementia in Hong Kong. Oral Health Prev Dent 13:51-57. https://doi.org/10.3290/j.ohpd.a32343

45. Cohen-Mansfield J, Lipson S (2002) The underdetection of pain of dental etiology in persons with dementia. Am J Alzheimers Dis Other Demen 17:249-253. https://doi.org/10.1177/ 153331750201700404

46. de Souza Rolim T, Fabri GMC, Nitrini R et al (2014) Oral infections and orofacial pain in Alzheimer's disease: a case-control study. J Alzheimers Dis 38:823-829. https://doi.org/10.3233/JAD-131283

47. Rolim T de S, Fabri GMC, Nitrini R et al (2014) Evaluation of patients with Alzheimer's disease before and after dental treatment. Arq Neuropsiquiatr 72:919-924. https://doi.org/10.1590/0004$282 \mathrm{X} 20140140$

48. Elsig F, Schimmel M, Duvernay E et al (2015) Tooth loss, chewing efficiency and cognitive impairment in geriatric patients. Gerodontology 32:149-156. https://doi.org/10.1111/ger.12079

49. Fjeld KG, Mowe M, Eide H, Willumsen T (2014) Effect of electric toothbrush on residents' oral hygiene: a randomized clinical trial in nursing homes. Eur J Oral Sci 122:142-148. https://doi.org/10. 1111/eos.12113

50. Gil-Montoya JA, Sánchez-Lara I, Carnero-Pardo C et al (2017) Oral hygiene in the elderly with different degrees of cognitive impairment and dementia. J Am Geriatr Soc 65:642-647. https://doi. org/10.1111/jgs. 14697

51. Gil-Montoya JA, Barrios R, Sánchez-Lara I et al (2016) Prevalence of drug-induced xerostomia in older adults with cognitive impairment or dementia: an observational study. Drugs Aging 33(8):611. https://doi.org/10.1007/s40266-016-0386-x

52. Hatipoglu MG, Kabay SC, Güven G (2011) The clinical evaluation of the oral status in Alzheimer-type dementia patients. Gerodontology 28:302-306. https://doi.org/10.1111/j.1741-2358. 2010.00401.x

53. Hoben M, Poss JW, Norton PG, Estabrooks CA (2016) Oral/dental items in the resident assessment instrument-minimum data set 2.0 lack validity: results of a retrospective, longitudinal validation study. Popul Health Metr 14:36. https://doi.org/10.1186/s12963016-0108-y

54. Hoeksema AR, Peters LL, Raghoebar GM et al (2016) Oral health status and need for oral care of care-dependent indwelling elderly: from admission to death. Clin Oral Investig. https://doi.org/10. 1007/s00784-016-2011-0

55. Ide M, Harris M, Stevens A et al (2016) Periodontitis and cognitive decline in Alzheimer's disease. PLoS One 11:e0151081. https://doi. org/10.1371/journal.pone.0151081

56. Kossioni AE, Kossionis GE, Polychronopoulou A (2012) Oral health status of elderly hospitalised psychiatric patients. Gerodontology 29:272-283. https://doi.org/10.1111/j.1741-2358. 2012.00633.x

57. Kossioni AE, Kossionis GE, Polychronopoulou A (2013) Selfreported oral complaints in older mentally ill patients. Geriatr Gerontol Int 13:358-364. https://doi.org/10.1111/j.1447-0594. 2012.00907.x

58. Leal SC, Bittar J, Portugal A et al (2010) Medication in elderly people: its influence on salivary pattern, signs and symptoms of dry mouth. Gerodontology 27:129-133. https://doi.org/10.1111/j. 1741-2358.2009.00293.x

59. Lee KH, Wu B, Plassman BL (2013) Cognitive function and oral health-related quality of life in older adults. J Am Geriatr Soc 61: 1602-1607. https://doi.org/10.1111/jgs.12402

60. Philip P, Rogers C, Kruger E, Tennant M (2012) Oral hygiene care status of elderly with dementia and in residential aged care facilities.
Gerodontology 29:e306-e311. https://doi.org/10.1111/j.17412358.2011.00472.x

61. Ribeiro GR, Costa JLR, Ambrosano GMB, Garcia RCMR (2012) Oral health of the elderly with Alzheimer's disease. Oral Surg Oral Med Oral Pathol Oral Radiol 114:338-343. https://doi.org/10.1016/ j.00oo.2012.03.028

62. Ship JA, DeCarli C, Friedland RP, Baum BJ (1990) Diminished submandibular salivary flow in dementia of the Alzheimer type. J Gerontol 45:M61-M66

63. Ship JA, Puckett SA (1994) Longitudinal study on oral health in subjects with Alzheimer's disease. J Am Geriatr Soc 42:57-63

64. Srisilapanan P, Jai-Ua C (2013) Oral health status of dementia patients in Chiang Mai Neurological Hospital. J Med Assoc Thail 96: 351-357

65. Sumi Y, Ozawa N, Michiwaki Y et al (2012) Oral conditions and oral management approaches in mild dementia patients. Nihon Ronen Igakkai Zasshi 49:90-98

66. Syrjälä A-MH, Ylöstalo P, Ruoppi P et al (2012) Dementia and oral health among subjects aged 75 years or older. Gerodontology 29: 36-42. https://doi.org/10.1111/j.1741-2358.2010.00396.x

67. Warren JJ, Chalmers JM, Levy SM et al (1997) Oral health of persons with and without dementia attending a geriatric clinic. Spec Care Dentist 17:47-53. https://doi.org/10.1111/j.1754-4505. 1997.tb00866.x

68. Zenthöfer A, Schröder J, Cabrera T et al (2014) Comparison of oral health among older people with and without dementia. Community Dent Health 31:27-31

69. Zenthöfer A, Cabrera T, Rammelsberg P, Hassel AJ (2016) Improving oral health of institutionalized older people with diagnosed dementia. Aging Ment Health 20:303-308. https://doi.org/ 10.1080/13607863.2015.1008986

70. Zenthöfer A, Baumgart D, Cabrera T et al (2017) Poor dental hygiene and periodontal health in nursing home residents with dementia: an observational study. Odontology 105:208-213. https://doi. org/10.1007/s10266-016-0246-5

71. Zenthöfer A, Meyer-Kühling I, Hufeland A et al (2016) Carers' education improves oral health of older people suffering from dementia - results of an intervention study. Clin Interv Aging 11: 1755-1762. https://doi.org/10.2147/CIA.S118330

72. Chalmers JM, Hodge C, Fuss JM et al (2002) The prevalence and experience of oral diseases in Adelaide nursing home residents. Aust Dent J 47:123-130. https://doi.org/10.1111/j.1834-7819. 2002.tb00315.x

73. Chalmers J, Carter K, Spencer A (2004) Oral health of Adelaide nursing home residents: longitudinal study. Australas J Ageing 23: 63-70. https://doi.org/10.1111/j.1741-6612.2004.00019.x

74. Chalmers JM, Carter KD, Spencer AJ (2005) Caries incidence and increments in Adelaide nursing home residents. Spec Care Dentist 25:96-105. https://doi.org/10.1111/j.1754-4505.2005.tb01418.x

75. Hopcraft MS, Morgan MV, Satur JG et al (2012) Oral hygiene and periodontal disease in Victorian nursing homes. Gerodontology 29: e220-e228. https://doi.org/10.1111/j.1741-2358.2010.00448.x

76. Zenthöfer A, Navratil SD, Rammelsberg P et al (2015) Oral health and apraxia among institutionalized elderly people - a pilot study. Acta Odontol Scand 73:150-155. https://doi.org/10.3109/ 00016357.2014 .961956

77. Robinson PG, Deacon SA, Deery C, et al (2005) Manual versus powered toothbrushing for oral health. Cochrane database Syst Rev CD002281. doi: https://doi.org/10.1002/14651858.CD002281. pub2

78. Tanasiewicz M, Hildebrandt T, Obersztyn I (2016) Xerostomia of various etiologies: a review of the literature. Adv Clin Exp Med 25: 199-206. 10.17219/acem/29375

79. Chalmers JM (2000) Behavior management and communication strategies for dental professionals when caring for patients with dementia. Spec Care Dentist 20:147-154 
80. Chalmers J, Pearson A (2005) Oral hygiene care for residents with dementia: a literature review. J Adv Nurs 52:410-419. https://doi. org/10.1111/j.1365-2648.2005.03605.x

81. De Visschere LMJ, van der Putten G-J, Vanobbergen JNOO et al (2011) An oral health care guideline for institutionalised older people. Gerodontology 28:307-310. https://doi.org/10.1111/j.17412358.2010.00406.x

82. Fiske J, Frenkel H, Griffiths J et al (2006) Oral health of people with dementia. Gerodontology 23:3-32. https://doi.org/10.1111/j.17412358.2006.00140.x

83. Pearson A, Chalmers J (2004) Oral hygiene care for adults with dementia in residential aged care facilities. JBI Libr Syst Rev 2:189. https://doi.org/10.1111/j.1479-6988.2004.00009.x

84. Attin T, Hornecker E (2005) Tooth brushing and oral health: how frequently and when should tooth brushing be performed? Oral Health Prev Dent 3:135-140

85. van der Putten GJ, De Visschere L, Vanobbergen J et al (2008) The guideline oral health care for dependent residents in long term care facilities, 2007: dire necessity. Tijdschr Gerontol Geriatr 39:202207

86. de Lugt-Lustig KHME, Vanobbergen JNO, van der Putten G-J et al (2014) Effect of oral healthcare education on knowledge, attitude and skills of care home nurses: a systematic literature review.
Community Dent Oral Epidemiol 42:88-96. https://doi.org/10. 1111/cdoe. 12063

87. Jablonski RA, Therrien B, Kolanowski A (2011) No more fighting and biting during mouth care: applying the theoretical constructs of threat perception to clinical practice. Res Theory Nurs Pract 25: $163-175$

88. Chalmers JM, King PL, Spencer AJ et al (2005) The oral health assessment tool-validity and reliability. Aust Dent J 50:191-199. https://doi.org/10.1111/j.1834-7819.2005.tb00360.x

89. Friedlander AH, Norman DC, Mahler ME et al (2006) Alzheimer's disease: psychopathology, medical management and dental implications. J Am Dent Assoc 137:1240-1251

90. Eichler T, Thyrian JR, Hertel J et al (2015) Rates of formal diagnosis of dementia in primary care: the effect of screening. Alzheimer's Dement (Amsterdam, Netherlands) 1:87-93. https://doi.org/10. 1016/j.dadm.2014.11.007

91. Folstein MF, Folstein SE, McHugh PR (1975) Mini-mental state. J Psychiatr Res 12:189-198. https://doi.org/10.1016/0022-3956(75) 90026-6

92. Kester MI, Scheltens P (2009) Dementia: the bare essentials. Pract Neurol 9:241-251. https://doi.org/10.1136/jnnp.2009.182477

93. Petersen PE, Baez RJ (2013) Oral health surveys: basic methods

94. Lewis D, Fiske J (2009) Guidelines for the delivery of a domiciliary oral healthcare service. J Disabil Oral Heal:1-44 